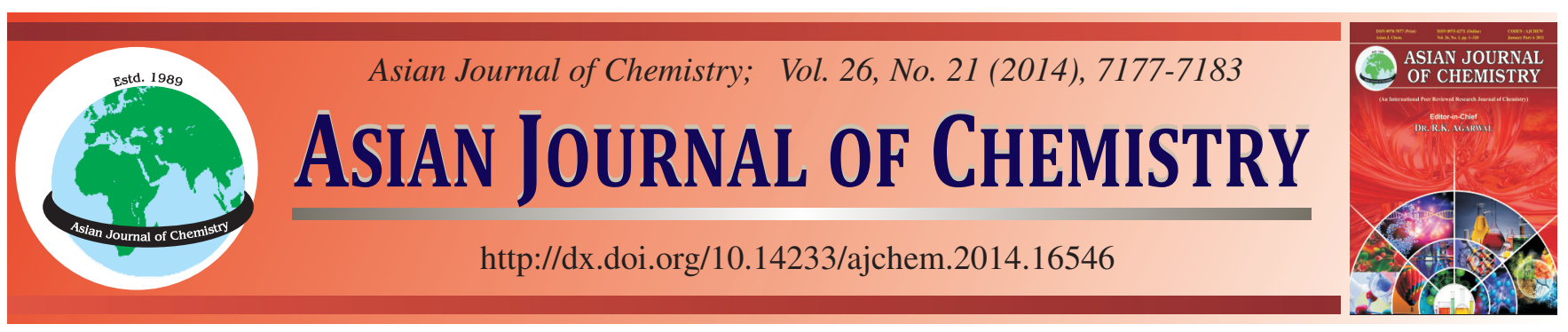

\title{
Chemical Composition, Antibacterial Activity and Mechanism of Action of Oil and Phenolics from AOF (Alpinia oxyphylla Miq.)
}

\begin{abstract}
W.X. CHEN ${ }^{*}$ and D. WANG
Department of Food Science and Technology, Hainan University, Haikou, P.R. China

*Corresponding author: Tel: +86 13976121821; E-mail: hnchwx@163.com; qiuqiujazz@126.com

Received: 18 October 2013;

Accepted: 24 January 2014;

Published online: 30 September 2014;

AJC-16097

In this study, antibacterial activity of the oils, phenolics and crude extracts were tested against two Gram-positive ( $S$. aureus, B. subtilis) and one Gram-negative (E. coli) bacteria by disc diffusion method and determining their minimum inhibitory concentration (MIC) values. The inhibition zones and MIC values for bacterial strains, were sensitive to the essential oil, phenolics and extracts of strains, were in the range of 8.2-21.8 $\mathrm{mm}$ and $156.25-1250 \mu \mathrm{g} / \mathrm{mL}$, respectively. The significant antibacterial activities, relationship between three different samples, mechanism of the antibacterial activity was also tested in bacteria growth kinetic and SEM. Moreover, to identify the components of the phenolics and oil, the phenolic composition was determined by HPLC-DAD and oil was determined by GC-MS. Among them, catechin, sygric acid, rutin, ellagic acid, chlorogenic acid, nootkatone, $\beta$-humulene, 8,9-dehydro cycloisolongifolene, etc. was determined, which was considered as the potential effective antibacterial composition.
\end{abstract}

Keywords: Alpinia oxyphyllae fructus, Phenolics, Oil, Antibacterial activities, Chemical composition, Mechanism.

\section{INTRODUCTION}

Foodborne outbreaks from microbial contamination, chemicals and toxins are common in many countries ${ }^{1}$. The burden of foodborne disease remains substantial and safety of food is an important health, social and economical issue which has become the global topic of increasing research efforts. There is considerable interest in alternative/adjuvant approaches for the eradication of infections using biologically active compounds, as food preservatives. The safety of food products with synthetic chemicals in some cases be in doubt and the products can thus potentially be detrimental to human health ${ }^{2}$. Amongst plants are important sources of bioactive compounds having antibacterial activity and other pharmaceutical effects ${ }^{3}$. Natural products which inhibit the growth of pathogenic bacteria in food have been developed and used since ancient times.

Alpinia oxyphylla Miq. (Zingiberaceae) is a usual conventional Chinese pharmacological and medicinal herb whose fruits are widely used to treat diarrhea, gastralgia, tonic, polyuria, aphrodisiac, anti-salivation and neuroprotection ${ }^{4-7}$. Studies about Alpinae Oxyphyllae Fructus (AOF), like, the pharmacological mechanism for AOF was attributed to anti-aging and sexual-reinforcing activities in experimental in vitro and in vivo systems ${ }^{8,9}$. The protective effect of AOF against 6-OHDAinduced neuronal injury involved antiinflammatory action ${ }^{10}$ and $\mathrm{A} \beta$-induced cell death was protected by the application of water extract of AOF in a dose-dependent manner and the effect to protect primary cultured neurons from N-methyl-Daspartate (NMDA) receptor-mediated glutamate toxicity ${ }^{11}$.

Available reports indicate their efficacy and to possess a broad spectrum of antimicrobial activity against various spoilage and pathogenic microorganisms, which is attributed to their bioactive constituents. They have been shown to have a wide range of biological activities, including antiallergic, antibacterial, antidiabetic, antiinflammatory, antiviral, antiproliferative, antimutagenic, antithrombotic, anticarcinogenic and antioxidant activities ${ }^{12-15}$.

Besides the high number of studies concerning the use of $\mathrm{AOF}$ as antimicrobial agents, there is still a lack of literature information involving similar combination of raw material type and preparation, extraction method and microbiological assays methodology applied to determine the antimicrobial activity, in order to compare the results.

Thus the main goal of this study was to evaluate the potential antimicrobial activity of AOF upon several food contaminants/potential pathogens, potentially functional bacteria, through the determination of the inhibition zones, minimum inhibitory concentration (MIC), growth inhibition curves and SEM. And the main components of AOF i.e., phenolics and oil was determined. 
EXPERIMENTAL

The Fructus Alpinia oxyphylla was purchased from Shounanshan Ginseng Industry Co., Ltd (Wuzhishan, Hainan, China). The antibacterial activity was screened against the Gram-positive bacteria, E. coli and Gram negative bacteria S. aureus and B. subtilis, obtained from the Food Microbiology Laboratory of Hainan University.

Extraction procedure: The Fructus Alpinia oxyphylla (AOF) samples were vacuum-dried at $60{ }^{\circ} \mathrm{C}$ for $24 \mathrm{~h}$, then smashed and then pass to 40-mesh sieve.

The essential oil (sample A) was extracted according to the method described by Viuda-Martos et al. with minor modifications ${ }^{16}$. Extraction of phenolics (sample B) was performed as described by Boulekbache-Makhlouf et al. ${ }^{17}$. The AOF crude extract (sample C) was prepared according to our previous study, the optimum conditions of Alpinae Oxyphyllae Fructus extraction with ultrasonic- microwave assisted method was as follows: ethanol concentration $73 \%$, extract temperature $54{ }^{\circ} \mathrm{C}$, liquid-material ratio $1: 5$ and extract time $45 \mathrm{~min}$. After drying, samples were stored in closed bottles and kept at -4 ${ }^{\circ} \mathrm{C}^{13}$. For the evaluation of antimicrobial activity, the dry AOF extracts were diluted in $80 \%$ of ethanol at a concentration of $100 \mu \mathrm{g}$ of $\mathrm{AOF} \mathrm{mL}^{-1}$ of solution, then filtered and stored protected from light.

Microbial strains: The antimicrobial activity of AOF extracts obtained by different extraction methods was evaluated against $S$. aureus, B. subtilis and E. coli. Mueller-Hinton agar and Broth media were used for microbial growth. Culture of each strain grown in Mueller-Hinton Broth was diluted to achieve a final concentration of $10^{7} \mathrm{CFU} / \mathrm{mL}$. All cultures were incubated in aerobic conditions ${ }^{18-19}$. All they were considered for the selection of the microorganisms ${ }^{20}$.

Disc diffusion assay: Antimicrobial susceptibility tests were carried out by Bauer's disc diffusion method ${ }^{21}$. Briefly, through the absorbance of the bacterial culture, the concentration was diluted to $10^{7} \mathrm{cfu} / \mathrm{mL}$ and plated on nutrient agar. The sterile discs (Whatman Filter Paper) were impregnated with aqueous extracts of $\mathrm{AOF}$ and $80 \%$ methanol as the positive control. The discs were applied on agar plates and incubated at $37^{\circ} \mathrm{C}$ for $16 \mathrm{~h}^{22}$.

Minimum inhibition concentration (MIC): Minimum inhibition concentration (MIC) was determined as described by Zampini et al. $^{23}$. Different concentrations $(10-2000 \mathrm{~g} / \mathrm{mL})$ of extract were tested. $1 \mathrm{~mL}$ of each solution was mixed with $9 \mathrm{~mL}$ of Muller Hinton medium and poured into sterilized Petri plates. Immediately after solidification, the plates were spot inoculated with $10 \mu \mathrm{L}$ of suspension containing $10^{7} \mathrm{CFU} /$ $\mathrm{mL}$ of each bacterium. The inoculated plates were incubated at $37{ }^{\circ} \mathrm{C}$ for $24 \mathrm{~h}$. The MIC values were determined as the lowest extract or standard concentrationat which no growth was observed.

Growth kinetics of selected bacterial strains: Solutions, at $2 \mathrm{MIC}$ concentration, were prepared and inoculated at $2 \%$ (v/v) using an inoculum of $10^{7} \mathrm{CFU} / \mathrm{mL}$ and incubated at $37^{\circ} \mathrm{C}$ for $24 \mathrm{~h}$. Bacterial growth were monitored every $2 \mathrm{~h}$ using turbidimetry (OD $600 \mathrm{~nm}$ ) over a period of $16 \mathrm{~h}$, with decimal dilutions and plated using the drop method as described by
Miles et $a l^{24}$. A positive control was drawn, for comparison purposes, using inoculated MHB without extract. Plates were then incubated for $24 \mathrm{~h}$ at $37^{\circ} \mathrm{C}$. All assays were done in duplicate.

Scanning electron microscope (SEM): To determine the efficacy of changes of bacteria strains, SEM observation was performed on the tested bacteria. The bacteria cells were incubated in nutrient broth at $37^{\circ} \mathrm{C}$ for $10 \mathrm{~h}$. The suspensions were added $2 \mathrm{MIC}$ of extract, phenolics and oil, respectively; control culture was left untreated. The suspensions were incubated at $37^{\circ} \mathrm{C}$ for $8 \mathrm{~h}$, respectively and then the suspensions were centrifuged.

The precipitated cells were washed twice with $0.1 \mathrm{M}$ PBS (pH 7.4) and fixed with $2.5 \%$ (v/v) glutaraldehyde in $0.1 \mathrm{M}$ PBS overnight a $4{ }^{\circ} \mathrm{C}$. After this, the cells were dehydrated using sequential exposure per ethanol concentrations ranging from 30 to $100 \%$ and the ethanol was replaced by tertiary butyl alcohol at last. Then, cells after centrifugation were dried at "critical point" in liquid $\mathrm{CO}_{2}$ under 95 bar pressure and samples were gold-covered by cathodic spraying. Finally, the bacterial cells was observed on a scanning electronic microscope (S-3000N, Hitachi Ltd., Japan).

GC-FID analysis: The essential oil (sample A) was analyzed using HewlettePackard 6890 equipped with flame ionization detector (FID) and DB-5 capillary column (30 m $\times$ $0.25 \mathrm{~mm}$; film thickness, $0.25 \mathrm{~mm}$ ), whose injector and detector temperatures were maintained at $250{ }^{\circ} \mathrm{C}$. The oven temperature was programmed from $80^{\circ} \mathrm{C}$ for $2 \mathrm{~min}$, raised to $200{ }^{\circ} \mathrm{C}$ at a rate of $10^{\circ} \mathrm{C} / \mathrm{min}$, raised to $250{ }^{\circ} \mathrm{C}$ at a rate of 6 ${ }^{\circ} \mathrm{C} / \mathrm{min}$ and isotherm at $250^{\circ} \mathrm{C}$ for $10 \mathrm{~min}$. Helium was the carrier gas, at a flow rate of $1 \mathrm{~mL} / \mathrm{min}$. A sample of $0.1 \mathrm{~mL}$ of essential oil was injected manually (in split mode 50:1).

GC-MS analysis: The analysis of the essential oil was performed using a HewlettePackard $6890 \mathrm{GC}$, equipped with a DB-5 MS capillary column $(30 \mathrm{~m} \times 0.25 \mathrm{~mm}$; film thickness, $1.40 \mathrm{um})$ and a HP624 mass selective detector for the separation. The mass selective detector was operated in electronimpact ionization (EI) mode with a mass scan range from $\mathrm{m} / \mathrm{z}$ 10 to 500 at $70 \mathrm{eV}$. GC conditions were the same as described above. The retention indices were calculated. The essential oil constituents were identified by comparing their GC retention indices, mass spectra with publish data and National Institute of Standards and Technology mass spectra library data provided by the software of GC-MS system. Essential oil components are reported as a relative per cent of the total oil by peak area.

HPLC analysis: Analytical HPLC was run on an Alliance HPLC-PDA system, equipped with a Agilent 1100 separation module (Agilent Co., USA), a quaternary pump and a Agilent diode array detector. The phenolics (sample B) separation was achieved on a HiCHROMÒRP C18 4.6*150*5 mm column. The solvents used were acetonitrile (phase A) and water-formic acid (98:2, v/v; phase B). The elution was carried out with a linear gradient $(0-5 \mathrm{~min}, \mathrm{~A}: \mathrm{B}=5: 95 ; 5-10 \mathrm{~min}, \mathrm{~A}: \mathrm{B}=15: 85$; 15-25 min, $\mathrm{A}: \mathrm{B}=40: 60 ; 25-30 \mathrm{~min}, \mathrm{~A}: \mathrm{B}=5: 95$ ) at flow rate of $1 \mathrm{~mL} / \mathrm{min}$. The detection was monitored at $300 \mathrm{~nm}$ and the components identified by comparison with commercial standards. 


\section{RESULTS AND DISCUSSION}

\section{Antimicrobial activity}

Disc diffusion method assay: With the purpose to determine the each concentration extract with capacity to inhibit bacteria growth, we select ${ }^{25}$ three concentration of 1000,500 , $250 \mathrm{mg} / \mathrm{L}$. The results obtained are represented in the Table-1.

After 24 h, $80 \%$ methanol was used as control and it exhibited a zone of inhibition of $6 \mathrm{~mm}$, suggesting no antibacterial activity. Else inhibition zones were in the range from 8.2 to $21.8 \mathrm{~mm}$, a positive result (inhibition zones $>6 \mathrm{~mm}$ ), demonstrating the significanty capacity of the AOF to inhibit bacteria growth. All the strains were found to be sensitive with maximum zone of inhibition obtained for Gram-positive of $S$. aureus $(21.8 \mathrm{~mm})$, the minimum zone for Gram-negative of $E$. coli $(8.2 \mathrm{~mm})$. And at the same concentration of the same sample, the resistance of bacteria was: $S$. aureus $<B$. subtilis $<E$. coli.

Zaika $^{26}$ proposed that Gram-positive bacteria are more resistant then Gramnegative bacteria to the antibacterial properties of plant extract which is in contrast to the hypothesis proposed by Deans and Ritchie ${ }^{27}$ that the susceptibility of bacteria to plant extract and the Gram reaction appears to have little influence on growth inhibition ${ }^{28}$. The same behavior was observed by Smith-Palmer et al..$^{29}$, Boussaada et $a l .^{30}$ and Michielin et al. ${ }^{19}$ studying extracts from other raw materials resistance of the Gram-negative bacteria is probably related to its two layer cell membrane and to the strong hydrophilicity of the outer membrane acting as a strong barrier, compared to the single membrane of the Gram-positive bacteria. Nevertheless, the study presented by Katalinic et al. ${ }^{31}$ related to grape skin extracts from 14 different varieties applied as antimicrobial agents show no significant differences in susceptibility of Gram-positive and Gram-negative bacteria.

Table-1 also shows that sample A was more effective than Sample B and C, with 7.1 and $7.8 \mathrm{~mm}$ larger at $1000 \mathrm{mg} / \mathrm{L}$ level on E. coli, 7.1 and $10.5 \mathrm{~mm}$ larger at $500 \mathrm{mg} / \mathrm{L}$ on $S$. aureus, 6.5 and $9.2 \mathrm{~mm}$ larger at $250 \mathrm{mg} / \mathrm{L}$. Sample A (essential oil ) was considered the significant antibacterial compounds. The antimicrobial properties and their constituents from a wide variety of plants have been assessed ${ }^{32}$ and reviewed ${ }^{33-37}$. Sample B extract has a high concentration of phenolics, mainly catechin and epicatechin and various procyanidins, it is likely that the antimicrobial properties of the extracts is linked with these compounds ${ }^{38,39}$.

In general, we observed a direct relationship between the studied concentrations and the size of inhibition zone for the three samples analyzed (Table-1). Similar results have been reported by Baydar et al. ${ }^{40}$.

Minimum inhibition concentration (MIC): MIC refers to the lowest concentration of the antimicrobial agent which is required for the inhibition of visible growth of the tested isolate. The negative control had no inhibition zone (inhibition zone $=6 \mathrm{~mm}$ ) formation, which suggested that the diluent (80\% methanol ) had no antimicrobial activity and therefore did not interfere with the MIC analysis. The MIC results for Gram-positive and Gram-negative bacteria are presented in Table-2.

\begin{tabular}{|c|c|c|c|}
\hline \multicolumn{4}{|c|}{$\begin{array}{c}\text { TABLE-2 } \\
\text { MIC OF SAMPLE A, B AND C FROM AOF }\end{array}$} \\
\hline & Extract & Phenolics & Oil \\
\hline E. coli & 1250 & 625.0 & 312.5 \\
\hline S. aureus & 625 & 312.5 & 156.25 \\
\hline B. subtilis & 625 & 625.0 & 312.5 \\
\hline
\end{tabular}

Duarte $e t a l{ }^{41}$ and Wang et $a l .{ }^{42}$ classified the extracts as: strong inhibitors for MIC value below $500 \mathrm{~g} / \mathrm{mL}$; moderate inhibitors for MIC between 600 and $1500 \mathrm{~g} / \mathrm{mL}$; weak inhibitors for MIC above $1600 \mathrm{~g} / \mathrm{mL}$. This classification is very useful to detect the potential of various plant materials with biological activity.

The sample A showed the lowest MIC values against S. aureus, $156.25 \mu \mathrm{g} / \mathrm{mL}$. Again, the sample A were more effective (lowest MIC values) against Gram-positive bacteria, mainly S. aureus, comparing to Gram-negative ones (E. coli). Only sample $\mathrm{C}$ showed weak activity against $E$. coli, inhibiting their growth with a MIC value of $1250 \mu \mathrm{g} / \mathrm{mL}$, while all other extracts behaved as moderate inhibitors against the Gramnegative bacteria. In this report, $\mathrm{AOF}$ has been found to be effective against bacterial pathogens causing food spoilage. And the antibacterial activity of the sample A,B,C agaist 3 different bacteria was in accordance with the result of disc diffsion assay, sample A has stronger, sample B weaker and C weakest antibacterial activity.

Although the size of the inhibition zone from disc diffusion assays indicates the strain sensibility to the antimicrobial substance, the inhibition size (Table-1) are not directly related to the samples potency by meansof MIC results ${ }^{25,43-45}$. For instance, the presented high inhibition zones against $B$. subtilis while its MIC values indicate weak inhibition.

Growth kinetics: The growth of $S$. enterica was strongly affected by sample A, followed by B and C. The pattern of growth for E. coli was similar in the presence of sample A, B and C. Finally, sample A proved to be the most effective compounds against Gram-positive bacteria.

Sample A, B and C showed a strong antimicrobial activity and caused a marked decrease of growth. These compounds increased the bacterial lag phase in most cases, even though significant differences between treated and control samples were found in only a few instances. The relatively large standard deviations observed could be responsible for the absence of significant differences.

\begin{tabular}{lccccccccc}
\multicolumn{10}{c}{ TABLE-1 } \\
\multicolumn{10}{c}{ DIAMETER OF INHIBITION ZONE OF SAMPLE A, B AND C FROM AOF } \\
\hline & \multicolumn{10}{c}{ Inhibition zones (mm) } \\
\hline & A1 & A2 & A3 & B1 & B2 & B3 & C1 & C2 & C3 \\
\hline E. coli & 18.6 & 12.5 & 7.8 & 11.5 & 9.0 & 7.2 & 10.8 & 9.9 & 8.2 \\
S. aureus & 21.8 & 15.0 & 9.8 & 14.7 & 11.9 & 9.0 & 11.3 & 10.3 & 9.2 \\
B. subtilis & 20.3 & 10.3 & 9.2 & 13.8 & 9.9 & 8.2 & 11.1 & 10.0 & 8.8 \\
\hline
\end{tabular}


Figs. 1-3 showed that in most of the cases ( $S$. aureus in the samples treated with phenolics and extracts, E. coli in the samples treated with oil, phenolics and B. subtilis in the samples treated with extracts) the increase in the growth rate was associated with an increase in the lag phase, with regard to controls. It is suggested that this prolongation of the lag phase could enable the bacteria to adapt to the compound in a certain extent, thus increasing their growth rate when the lag phase ends.

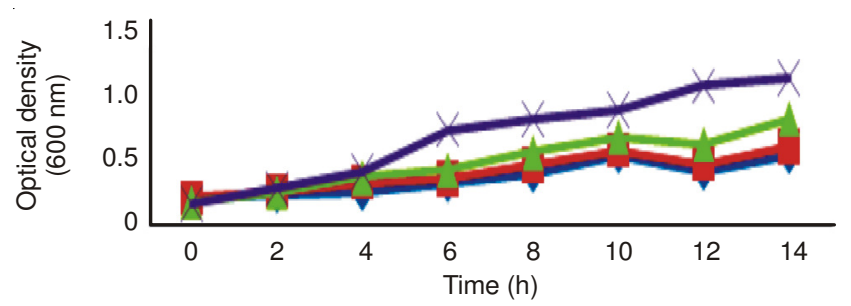

$\multimap$ Sample A $\neg$ Sample B $\leftarrow$ Sample C $\longleftarrow$ Control

Fig. 1. Growth curves of E. coli in the presence of Sample A, B and C at the concentration 2 MIC of growth medium

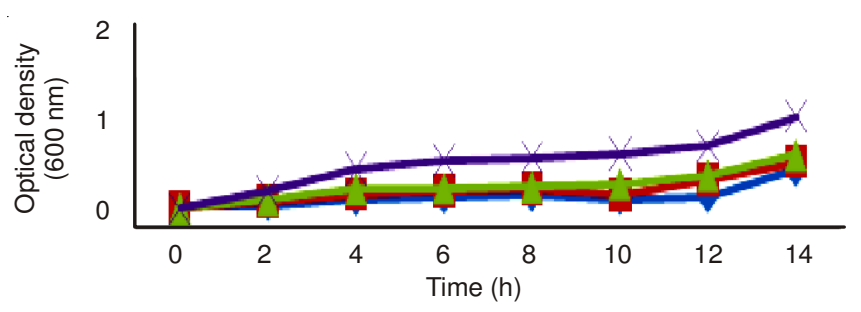

$\multimap$ Sample A Sample B Sample $C \multimap$ Control

Fig. 2. Growth curves of S. aureus in the presence of Sample A, B and C at the concentration 2 MIC of growth medium

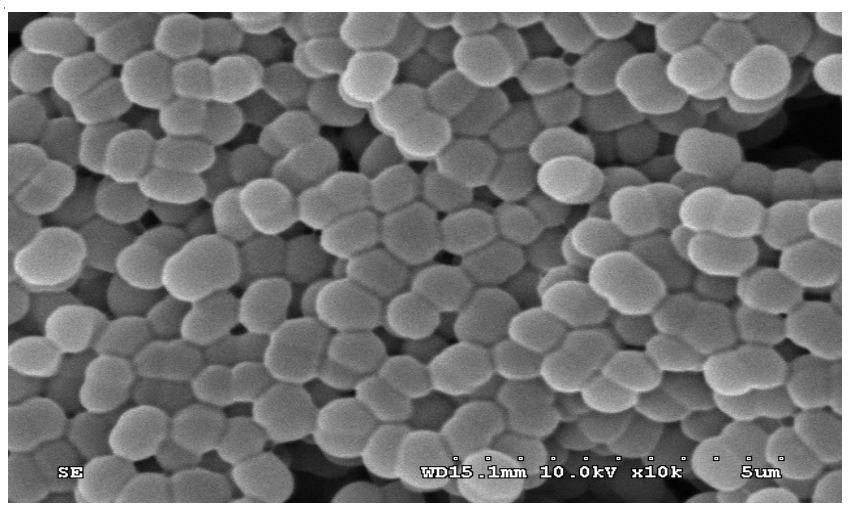

(a)

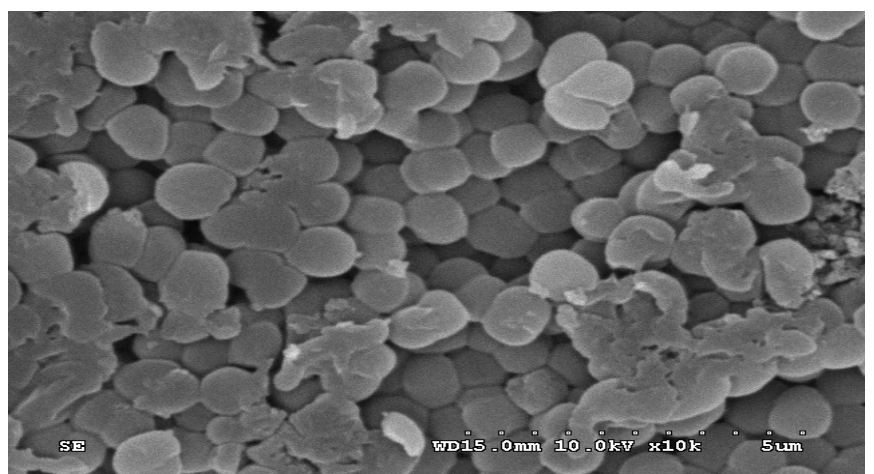

(c)

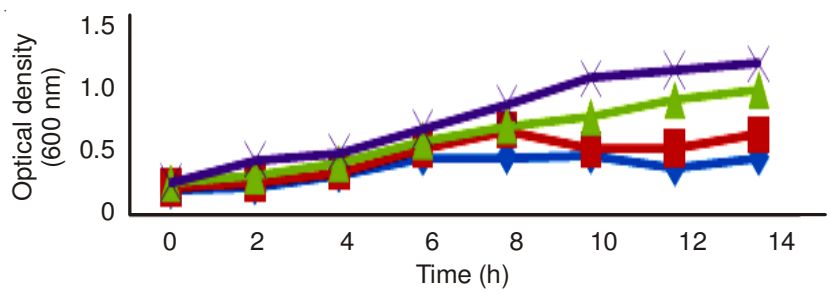

$\multimap$ Sample A Sample B Sample C Control

Fig. 3. Growth curves of B. subtilis in the presence of Sample A, B and C at the concentration 2 MIC of growth medium

Scanning electron microscope study: They were treated with the A, B, C from AOF at 2 MIC for $8 \mathrm{~h}$ respectively and then the changes of treated bacteria were observed by SEM. Figs. 4-6 showed the SEM images of the treated and untreated bacteria. These images directly illustrated the destructive effects of the AOF on the tested bacteria. The surfaces of the treated strains underwent obvious morphological changes compared with the untreated controls. Untreated cells were rod shaped, regular and intact (Figs. 4a, 5a, 6a), while some bacterial cells treated with the AOF became deformed, pitted, shriveled, adhesive to each other and parts of the cell were broken (Figs. 4a-c, 5a-c, 6a-c), which may give rise to the leaching out of nutrient and genetic materials. Moreover, bacterial cells treated with sample A was in largest damage, treated with sample B was smaller and extract was smallest. And this supported the results indicated that AOF may have severe effects on the cell wall and cytoplasmic membrane.

GC-MS of oil extracts: Report presents of 30 compounds representing $97.77 \%$ of the oil (sample A) with nootkatone (21.96\%), naphthalene, 1,2,3,5,6,7,8,8a-octahydro-1,8a-

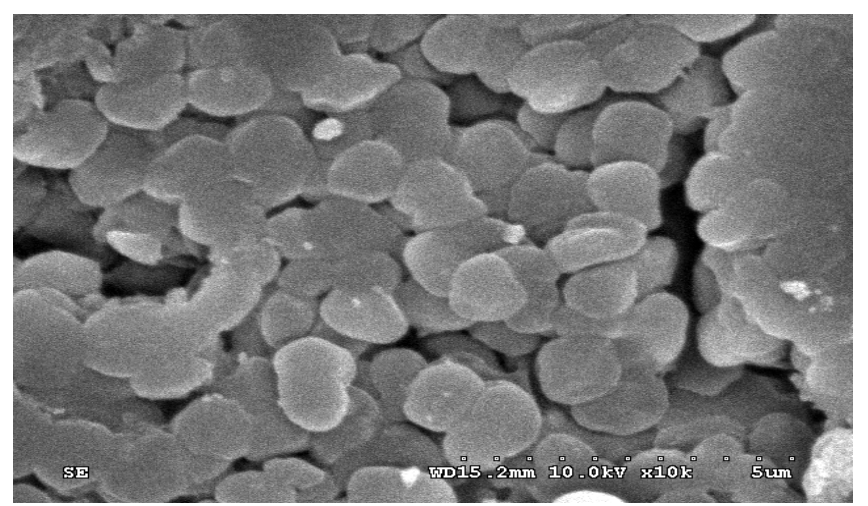

(b)

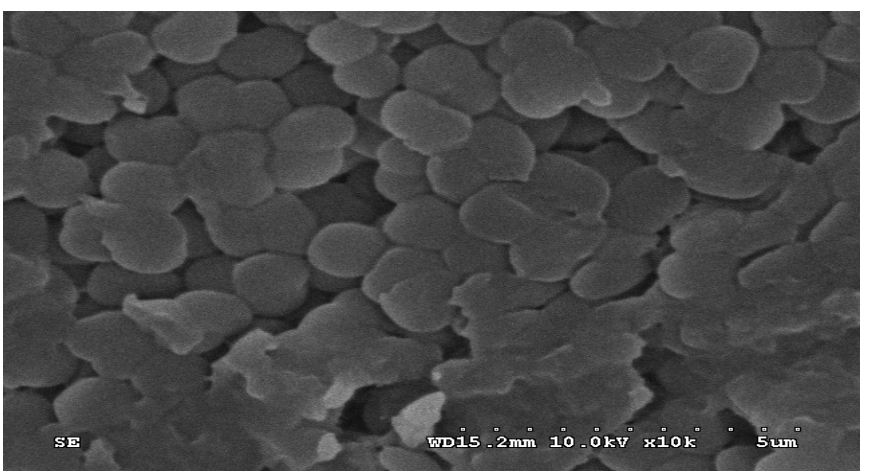

(d)

Fig. 4. Scanning electron micrographs indicating cell wall ruptures of S. aureus, (a: untreated; b: Sample A treated; c: Sample B treated; d: Sample C treated) 


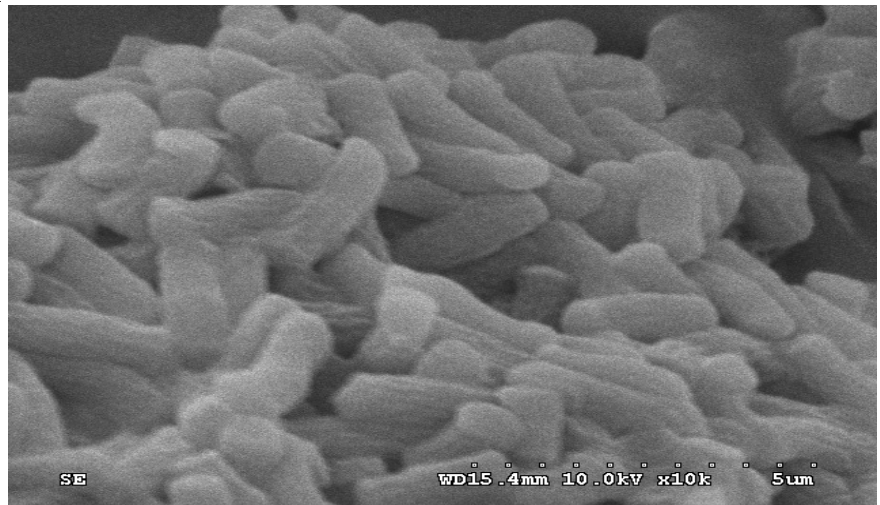

(a)

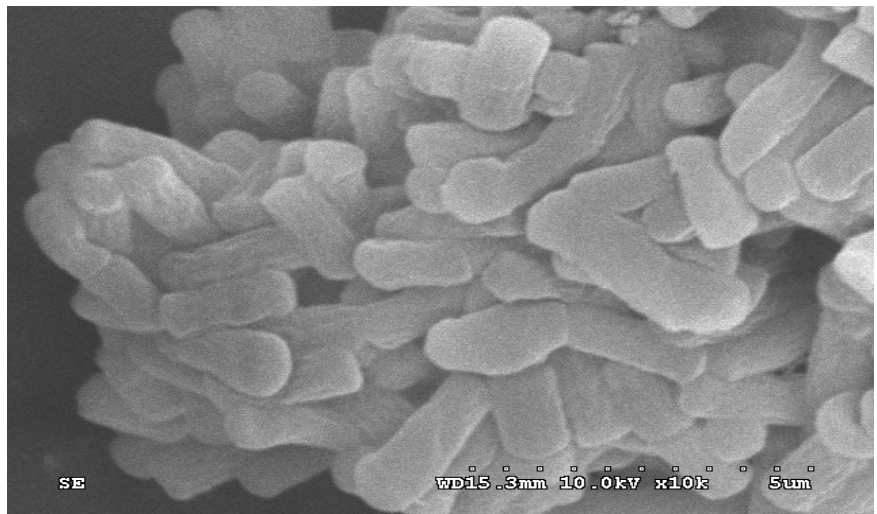

(c)

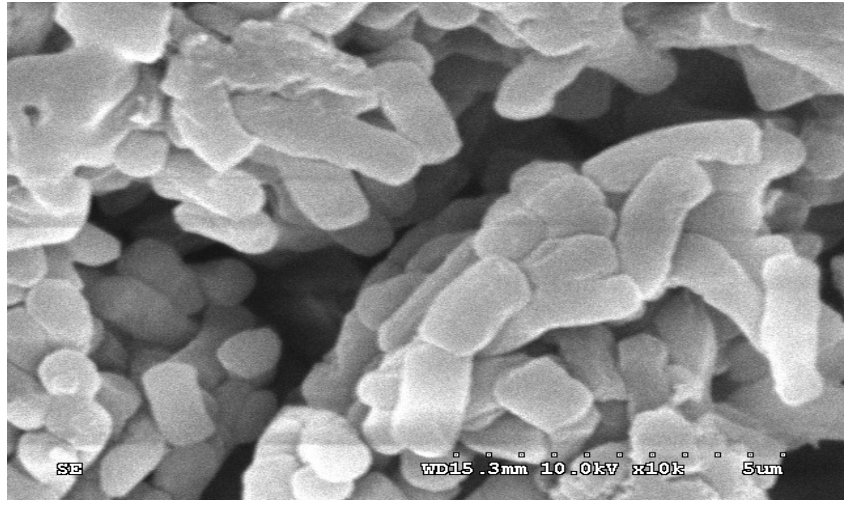

(b)

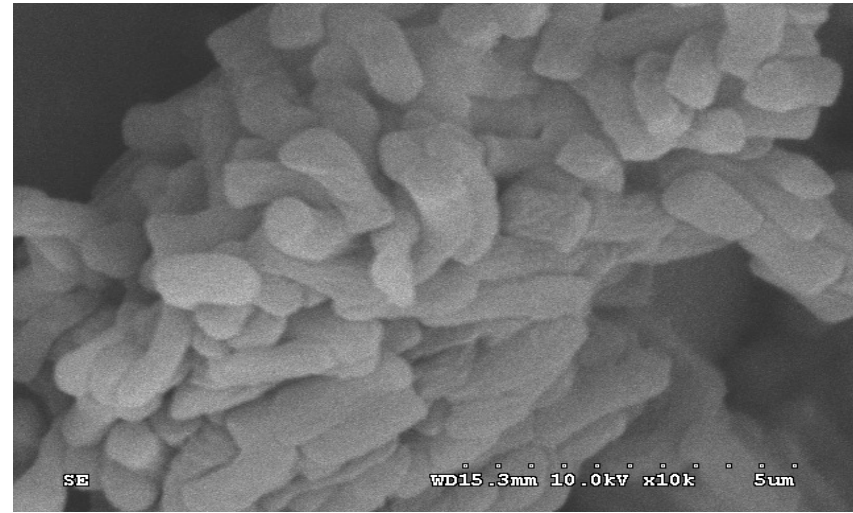

(d)

Fig. 5. Scanning electron micrographs indicating cell wall ruptures of E. coli, (a: untreated; b: Sample A treated; c: Sample B treated; d: Sample C treated)

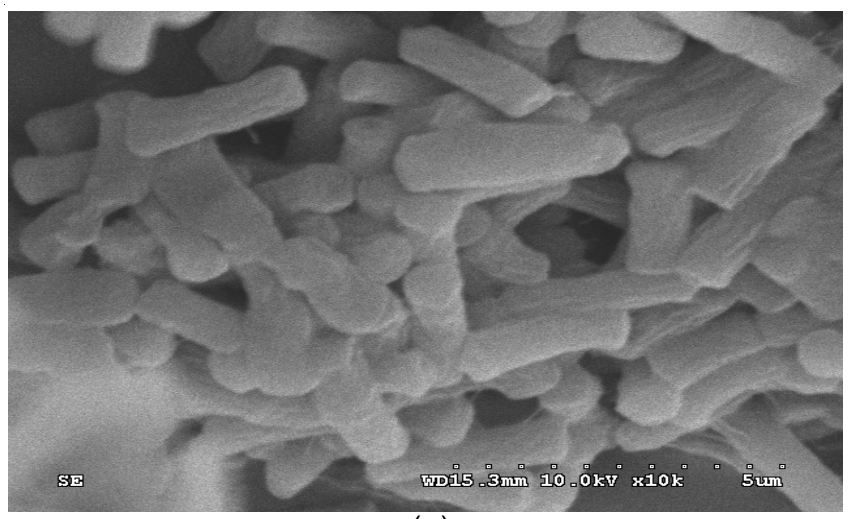

(a)

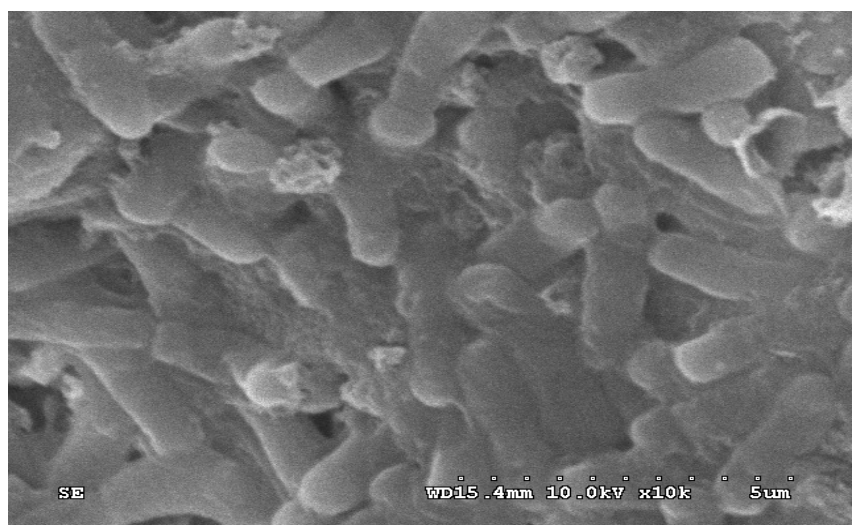

(c)

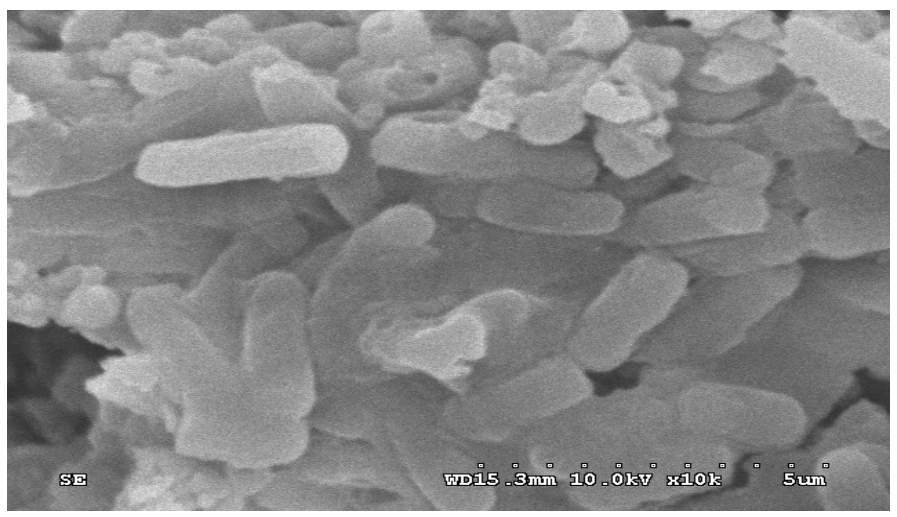

(b)

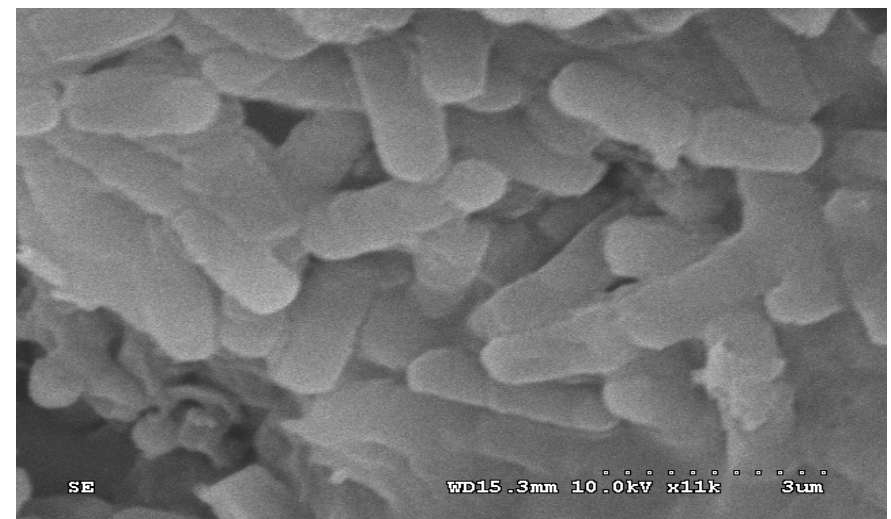

(d)

Fig. 6. Scanning electron micrographs indicating cell wall ruptures of B. subtili, (a: untreated; b: Sample A treated; c: Sample B treated; d: Sample C treated) 
dimethyl-7-(1-methylethenyl)-[1R-(1 $\alpha, 7 \beta, 8 \mathrm{a} . \alpha)]$ (19.11\%), (-)- $\alpha$-panasinsen $(7.45 \%), 2,5$-cyclohexadiene-1,4-dione, 2,6bis(1,1-dimethylethyl)-(6.03\%), $\beta$-humulene $(3.84 \%), 8,9$ dehydro-cycloisolongifolene $(3.77 \%)$ as the major constituents that contributed to the antibacterial activity of the essential oil. Results show that compounds of oil were mostly terpenoids and oxygenated derivatives.

HPLC of phenolic extracts: In Fig. 7 are shown the individual phenolic (sample B) compounds in AOF and its collected fractions detected by HPLC. The phenolic profile of AOF mainly consisted on flavonols and phenolic acids.

Our extracts contains five compounds including catechin (compound 1), sygric acid (compound 2), lutin (compound 3), ellagic acid (compound 4), chlorogenic acid (compound 5) obtained from Sample B which was also analyzed by HPLC (Fig. 7)

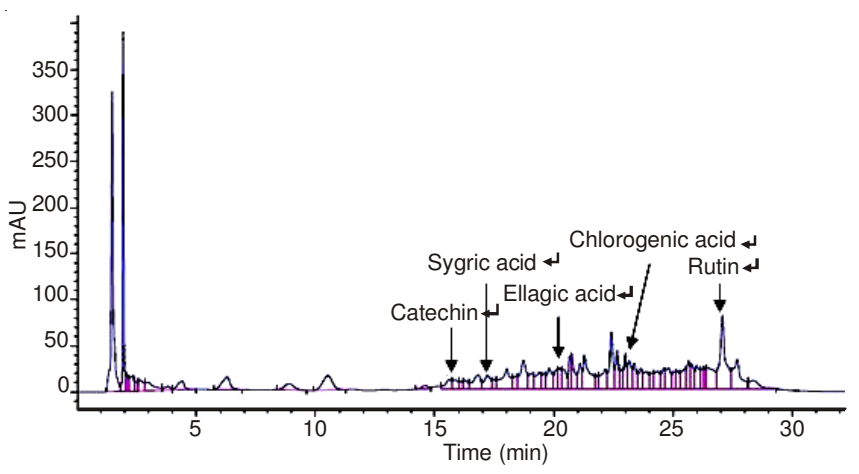

Fig. 7. HPLC chromatograms of the AOF extracts

Based on the present research, the AOF extract, which was rich in oil and phenolics, possessed good antibacterial activity against selected food-borne pathogens in this study. The best antibacterial activity was presented by the oil extract (sample A) presenting a moderate inhibition against all three microrganism tested, the better one was the phenolics extract (sample B) and the crude extract has weakest antibacterial activities.

The constituent of oil an phenolics was determined through HPLC and GC-MS respectively. Catechin, sygric acid, rutin, ellagic acid, chlorogenic acid, nootkatone, naphthalene1,2,3,5,6,7,8,8a-octahydro-1,8a-dimethyl-7-(1-methylehenyl)-, [1R-(1 $\alpha, 7 \beta, 8-a . \alpha)]-,(-)-\alpha$-panasinsen-2,5-cyclohexadiene1,4-dione, 2,6-bis(1,1-dimethylethyl)-, $\beta$-humulene, 8,9dehydro-cycloisolongifolene was determined, which was considered as the potential effective antibacterial composition.

The activity of the samples would be expected to relate to the respective composition, the structural configuration of the constituent components and their functional groups and possible synergistic interactions between components. Neverthless, according to Borchers et al. ${ }^{46}$, natural extracts may be more beneficial than isolated constituents, as the synergic positive interaction of compounds may change the properties of bioactive individual components.

Antibacterial activities was firstly a break through the permeability of cell membrane associated with generalized the integrality of membrane-disrupting effects, leading to the leakage of electrolytes as well as losses of proteins, reducing sugars. These changes resulted in cell decomposition and death, and the SEM observation supported the above hypothesis.

It is not confirmed whether there is one mechanism of action or that only one component is responsible for the antimicrobial action. Therefore, further research is still necessary to fully understand the mechanisms involved including against other food-borne pathogens. TEM observation as well as the interactions with other food ingredients in order to justify the real applications of $\mathrm{AOF}$ in food practices as a natural antibacterial agent.

\section{ACKNOWLEDGEMENTS}

This work was supported by the Natural Science Foundation of Hainan Province of China (312073, 211008); Dr Foundation of Hainan University (kyqd1224).

\section{REFERENCES}

1. WHO, The World Health Report; Global Public Health Security in the 21st Century, World Health Organization, Geneva (2007).

2. V.K. Bajpai and S.C. Kang, J. Biosci., 35, 533 (2010).

3. B. Yang, F. Chen, Y.L. Hua, S.S. Huang, S. Lin, L.R. Wen and Y. Jiang, Food Chem., 131, 508 (2012)

4. X. Yu, L. An, Y. Wang, H. Zhao and C. Gao, Toxicol. Lett., 144, 205 (2003).

5. G.F. Shi, L.J. An, B. Jiang, S. Guan and Y.M. Bao, Neurosci. Lett., 403, 206 (2006).

6. Y.-M. Shui Guan, Y.-M. Bao, Bo Jiang and L.-J. An, Eur. J. Pharmacol., 538, 73 (2006).

7. X. Zhang, G.F. Shi, X.Z. Liu, L.- An and S. Guan, Cell Biochem. Funct., 29, 342 (2011).

8. X. Chen, Y. Jia and B. Wang, Chung Kuo Chung Yao Tsa Chih, 107, 17 (1992).

9. W.H. Lee and J.C. Chung, J. Korean Oriental Intern. Med., 381, 19 (1998).

10. Z.J. Zhang, L.C.V. Cheang, M.-W. Wang, G.-H. Li, I.K. Chu, Z.-X. Lin and S.M.Y. Lee, Cell. Mol. Neurobiol., 32, 27 (2012).

11. B.S. Koo, W.C. Lee, Y.-C. Chang and C.-H. Kim, Phytother. Res., 18, 142 (2004)

12. G. Sibi, R. Naveen, K. Dhananjaya, K.R. Ravikumar and H. Mallesha, Pharmacogn. J., 4, 44 (2012).

13. O. Sagdic, A.G. Karahan, M. Ozcan and G. Ozkan, Food Sci. Technol. Int., 9, 353 (2003).

14. M.M. Ozcan, J.C. Chalchat, D. Arslan, A. Ates and A. Unver, J. Med. Food, 9, 552 (2006).

15. L. Salgueiro, A.P. Martins and H. Correia, Flav. Fragr. J., 25, 253 (2010).

16. M. Viuda-Martos, M.A. Mohamady, J. Fernández-López, K.A. Abd El-Razik, E.A. Omer, J.A. Pérez-Alvarez and E. Sendra, Food Contr., 22, 1715 (2011).

17. L. Boulekbache-Makhlouf, E. Meudec, M. Chibane, J.-P. Mazauric, S. Slimani, M. Henry, V. Cheynier and K. Madani, J. Agric. Food Chem., 58, 12615 (2010)

18. J.A. Smânia, F.D. Monache, E.F. Smânia, M.L. Gil, L.C. Benchetrit and F.S. Cruz, J. Ethnopharmacol., 45, 177 (1995).

19. E.M.Z. Michielin, A.A. Salvador, C.A.S. Riehl, J.R.A. Smânia Jr., E.F.A. Smânia and S.R.S. Ferreira, Bioresour. Technol., 100, 6615 (2009).

20. M.V. Olson, C.K. Stover, X.Q. Pham, A.L. Erwin, S.D. Mizoguchi, P. Warrener, M.J. Hickey, F.S.L. Brinkman, W.O. Hufnagle, D.J. Kowalik, M. Lagrou, R.L. Garber, L. Goltry, E. Tolentino, S. Westbrock-Wadman, Y. Yuan, L.L. Brody, S.N. Coulter, K.R. Folger, A. Kas, K. Larbig, R. Lim, K. Smith, D. Spencer, G.K.-S. Wong, Z. Wu, I.T. Paulsen, J. Reizer, M.H. Saier, R.E.W. Hancock and S. Lory, Nature, 406, 959 (2000).

21. A.W. Bauer, W.M. Kirby, J.C. Sherris and M. Turck, Am. J. Clin. Pathol., 45, 493 (1966).

22. M.R.S. Zaidan, A. Noor Rain, A.R. Badrul, A. Adlin, A. Norazah and I. Zakiah, Trop. Biomed., 22, 165 (2005).

23. I.C. Zampini, M.A. Vattuone and M.I. Isla, J. Ethnopharmacol., 102, 450 (2005). 
24. A.A. Miles, S.S. Misra and J.O. Irwin, J. Hyg., 38, 732 (1938).

25. D. Wang and W.X. Chen, Asian J. Chem., 26, 2057 (2014).

26. L.L. Zaika, J. Food Nutr., 9, 97 (1988).

27. S.G. Deans and G. Ritchie, Int. J. Food Microbiol., 5, 165 (1987).

28. S.G. Deans, R.C. Noble, R. Hiltunen, W. Wuryani and L.G. Penzes, Flavour Fragrance J., 10, 323 (1995).

29. A. Smith-Palmer, J. Stewart and L. Fyfe, Lett. Appl. Microbiol., 26, 118 (1998).

30. O. Boussaada, S. Ammar, D. Saidana, J. Chriaa, I. Chraif, M. Daami, A.N. Helal and Z. Mighri, Microbiol. Res., 163, 87 (2008).

31. V. Katalinic, S.S. Mo•ina, D. Skroza, I. Generalic, H. Abramovic, M. Miloš, I. Ljubenkov, S. Piskernik, I. Pezo and P. Terpinc, Food Chem., 119, 715 (2010)

32. M. Lis-Balchin and S.G. Deans, J. Appl. Microbiol., 82, 759 (1997).

33. C.F. Carson, B.D. Cookson, H.D. Farrelly and T.V. Riley, J. Antimicrob. Chemother., 35, 421 (1995).

34. J.V. Larrondo, M. Agut and M.A. Calvo-Torras, Microbios, 82, 171 (1995).

35. S. Pattnaik, V.R. Subramanyam, C.R. Kole and S. Sahoo, Microbios, 84, 239 (1995).
36. C.F. Carson, K.A. Hammer and T.V. Riley, J. Antimicrob. Chemother., 37, 1177 (1996).

37. P. Nenoff, U.F. Haustein and W. Brandt, Skin Pharmacol. Physiol., 9, 388 (1996).

38. J. Piljac-Zegarac, A. Belscak and A. Piljac, J. Med. Food, 12, 608 (2009).

39. K. Riihinen, L. Jaakola, S. Karenlampi and A. Hohtola, Food Chem., 110, 156 (2008).

40. H. Baydar, O. Sagdic, G. Ozkan and T. Karadogan, Food Contr., 15, 169 (2004).

41. M.C.T. Duarte, E.E. Leme, C. Delarmelina, A.A. Soares, G.M. Figueira and A. Sartoratto, J. Ethnopharmacol., 111, 197 (2007).

42. Y.S. Wang, H.P. He, J.H. Yang, Y.T. Di and X.J. Hao, Molecules, 13, 931 (2008)

43. J.L. Rios, M.C. Recio and A. Villar, J. Ethnopharmacol., 23, 127 (1988).

44. C.S.G. Kitzberger, A. Smânia Jr., R.C. Pedrosa and S.R.S. Ferreira, J. Food Eng., 80, 631 (2007).

45. C. Papadopoulou, K. Soulti and I.G. Roussis, Food Technol. Biotechnol., 41, 43 (2005).

46. A.T. Borchers, C.L. Keen and M.E. Gerstiwin, Exper. Biol. Med., 229, 393 (2004). 